\title{
29. VARIATIONS IN TRACE ELEMENT CONTENTS AND ISOTOPIC COMPOSITIONS OF LOWER CRETACEOUS CARBONATES FROM THE GALICIA MARGIN (ODP LEG 103): RECONSTRUCTION OF THE PALEOCHEMISTRY OF THE EARLY CRETACEOUS OCEAN1
}

\author{
Sebastian Clauser, ${ }^{2}$ Maurice Renard, and Gilbert Richebois, Université Pierre et Marie Curie, Département de \\ Géologie Sédimentaire et U.A. CNRS 319, Paris, France
}

\begin{abstract}
Trace element contents ( $\mathrm{Sr}, \mathrm{Mg}, \mathrm{Mn}$, and $\mathrm{Fe}$ ) and the composition of oxygen and carbon isotopes show that late burial diagenesis did not play an important role in pelagic carbonate chemistry in the bulk carbonates recovered from Holes 638B, 638C, and 641C (except for anoxic pore-water diagenesis in Valanginian sediments). The evolution of these different geochemical markers documents the importance and global extent of the Barremian ocean chemistry crisis. A reconstruction of paleoceanographic and climatic conditions during the Early Cretaceous is proposed. Sea level rose eustatically from the early Hauterivian to early Albian, but a rapid down and up fluctuation occurred during the Barremian. Soluble supply from the continent decreased during the Valanginian-early Hauterivian while oceanic hydrothermal supply increased. The climate cooled slightly during the Hauterivian, rapidly warmed during the Barremian, and cooled again during the Aptian.
\end{abstract}

\section{INTRODUCTION}

Previous studies of pelagic sediments from various Deep Sea Drilling Project (DSDP) sites and continental outcrops (summarized in Renard, 1985, 1986b) have shown several things. First, these studies have documented that the influence of late burial diagenesis on the geochemistry of these sediments is considerably less than was originally thought (Veizer, 1977; Renard, 1979; Renard et al., 1978; Baker et al., 1982). Second, numerous chemical fluctuations, such as changes in $\mathrm{Sr} / \mathrm{Ca}, \mathrm{Mg} / \mathrm{Ca}$, and ${ }^{13} \mathrm{C} /{ }^{12} \mathrm{C}$ ratios, have occurred in the ocean during the last 140 m.y. Fluctuations may be controlled by variations in submarine hydrothermal activity, which modify chemical element production or consumption at mid-ocean ridges, and by sea-level fluctuations, which control the chemical element input/output from the ocean via the erosion/sedimentation balance. Third, the studies have shown that bulk carbonate geochemistry data are important in both paleoceanography and stratigraphy.

An important change in ocean chemistry that occurred during the Barremian (Renard, 1986a) seems to mark the transition between the modern ocean and the ancient Jurassic ocean (Sliter and Premoli Silva, 1985). The purpose of this work was to find if this change is recorded in the sediments recovered during Ocean Drilling Program (ODP) Leg 103.

\section{METHODS}

Abundances of strontium, magnesium, manganese, and iron relative to the carbonate fraction were measured in samples ranging in age from Valanginian to Albian ( 40 samples from Hole 638B, 12 samples from Hole 638C, 6 samples from Hole 639D, and 35 samples from Hole 641C). After crushing, the samples were washed with distilled water to eliminate interstitial water. The conductivity of the wash water was measured after each centrifugation, and treatment was stopped when the decreasing conductivity reached a plateau. X-ray diffraction (Compagnie Générale de Radiologie apparatus) revealed mainly low-magnesium calcite, but traces of dolomite and siderite were also observed in samples from Holes 638C and 639D. The presence of several different mineralogical types of carbonates, in addition to an overall low carbonate con-

\footnotetext{
${ }^{1}$ Boillot, G., Winterer, E. L., et al., 1988. Proc. ODP, Sci. Results, 103: College Station, TX (Ocean Drilling Program).

${ }^{2}$ Also at: B.R.G.M., Orléans, France.
}

tent, led to the rejection of samples from Holes 638C and 639D for trace element analysis; however, a few samples from these two holes were used for the isotope study.

After pretreatment, the samples were dissolved in $1 \mathrm{~N}$ acetic acid. Trace element analyses were conducted by atomic absorption on an IL 551 apparatus. To compensate for possible contamination resulting from flushing of the insoluble residue (i.e., interlayer cations in clay minerals), the results shown in Figures 1 and 2 are normalized to a $100 \%$ $\mathrm{CaCO}_{3}$ sediment using the equation of Renard (1985), as for Sr:

$$
\mathrm{Sr}_{100}=\left[\mathrm{Sr}(\mathrm{ppm}) \times \mathrm{CaCO}_{3}(\%)\right] / 100
$$

Oxygen and carbon isotope ratios were measured on a VG Micromass 602 mass spectrometer. Results are given in parts per mil (\%) with respect to the PDB1 standard. The non-normalized analytical results are summarized in Table 1.

\section{TRACE ELEMENT RESULTS}

\section{Evolution vs. Depth at Hole 641C}

Samples studied from Hole $641 \mathrm{C}$ range in age from Albian (Sample 103-641C-1R-1, 10-12 cm; $160 \mathrm{~m}$ below seafloor [mbsf]) to late Barremian (Sample 103-641C-16R-8, 55-57 cm; 305.05 mbsf). Lithology (see "Site 641" chapter; Shipboard Scientific Party, 1987b) varies from greenish gray and black claystone (lithologic Unit IIIB, Albian), to greenish gray marlstone with limestone conglomerate and microturbidites (Units IV and V, Aptian), and to gray marlstone with microturbidites (Unit VI, upper Barremian). Because of the low carbonate contents, results from Cores 103-641C-1R and 103-641C-3R should be viewed with caution.

\section{Strontium}

$\mathrm{Sr}$ content increases with depth in Hole $641 \mathrm{C}$, from about $200 \mathrm{ppm}$ in Core 103-641C-1R to about $700 \mathrm{ppm}$ in Sample 103$641 \mathrm{C}-16 \mathrm{R}-8,55-57 \mathrm{~cm}$. In addition to this general trend, shortterm fluctuations in $\mathrm{Sr}$ content allow us to distinguish four geochemical zones in the hole (Fig. 1):

1. Zone I: Samples $103-641 \mathrm{C}-1 \mathrm{R}-1,10-12 \mathrm{~cm}$, to $103-641 \mathrm{C}-$ $7 \mathrm{R}-1,115-117 \mathrm{~cm}$, (160 to $209.85 \mathrm{mbs}$ ) have a low $\mathrm{Sr}$ content (about $200 \mathrm{ppm}$ ). 
Table 1. Results of carbonate trace elements and carbon and oxygen isotopes analyses.

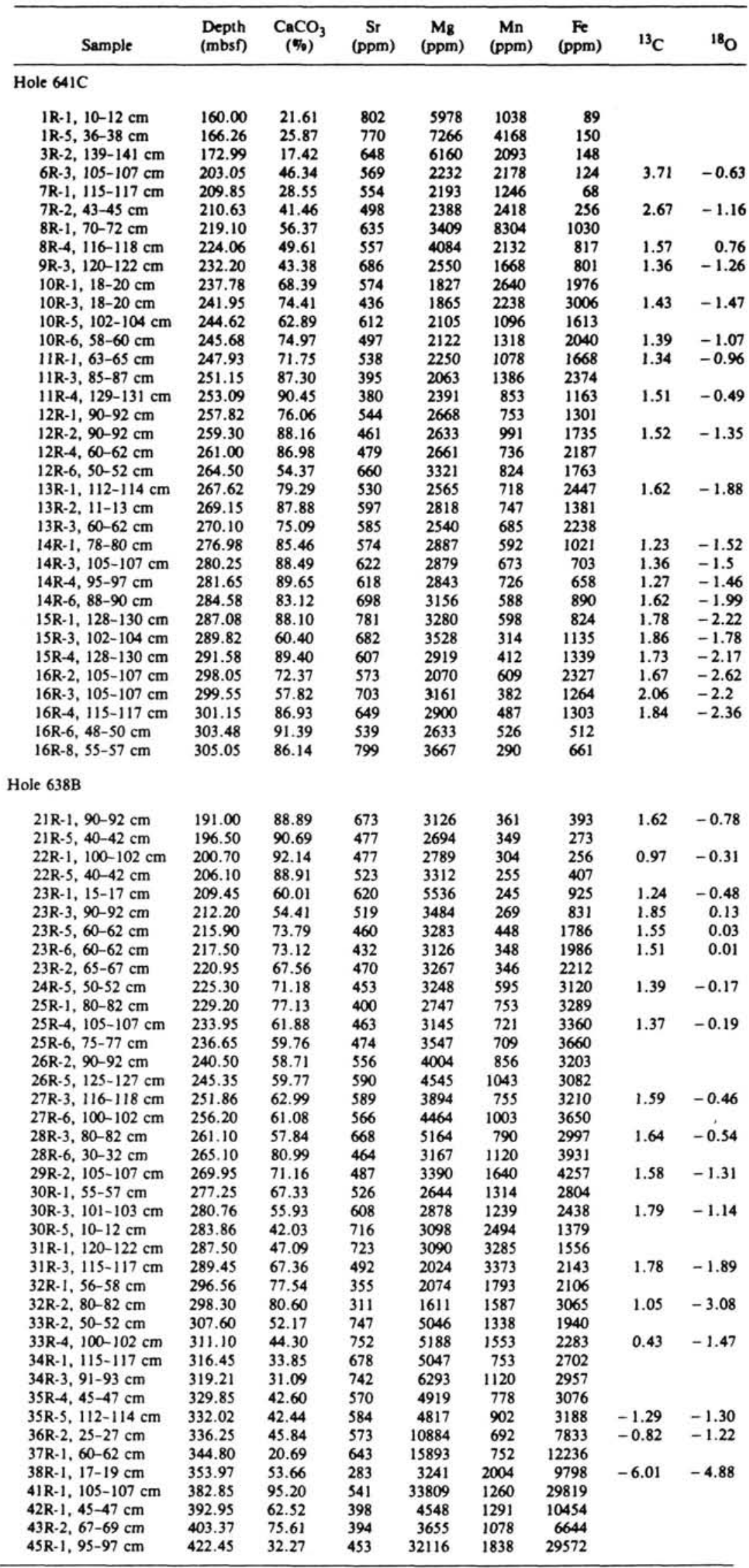



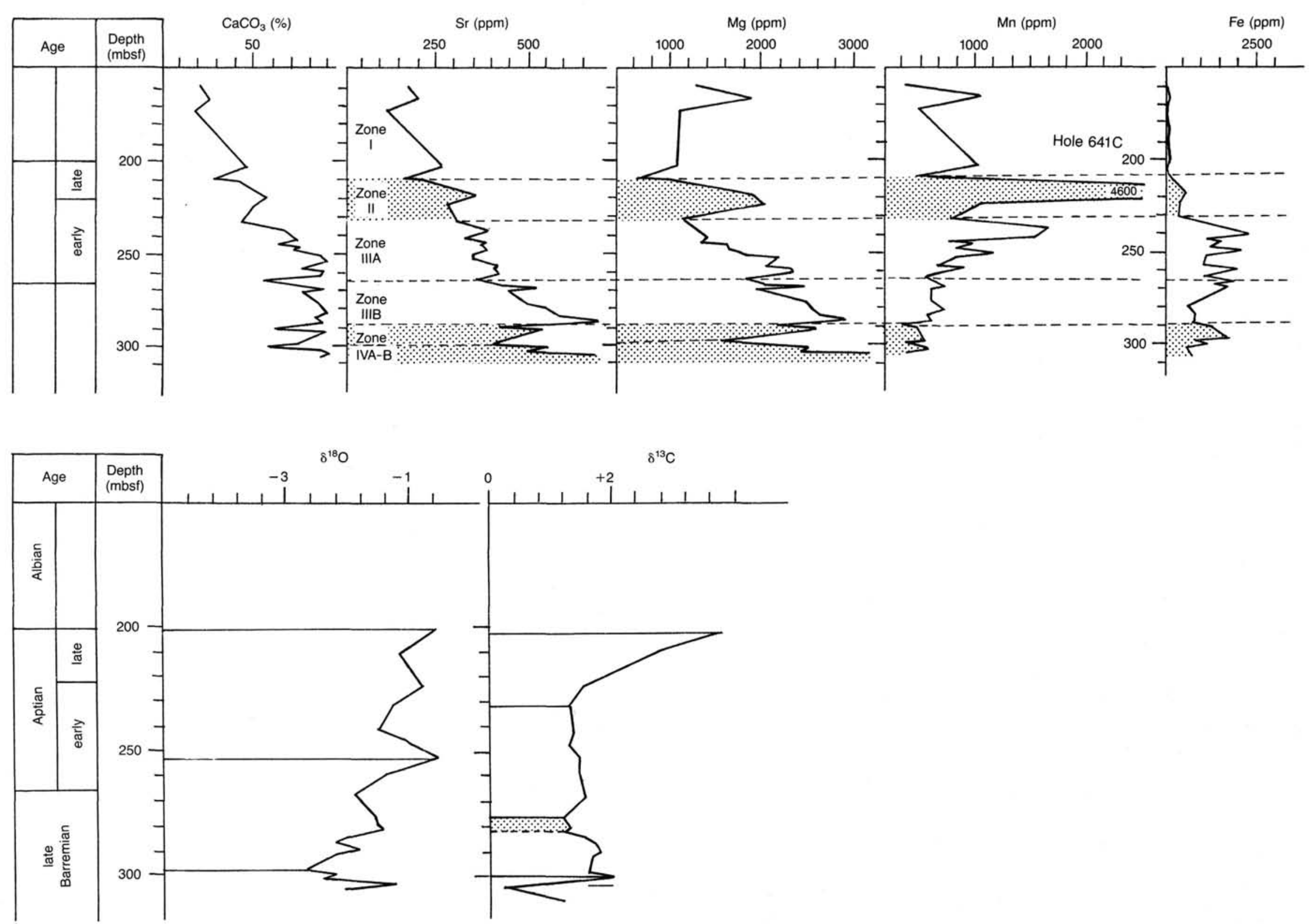

Figure 1. Trace element contents and $\delta^{18} \mathrm{O}$ and $\delta^{13} \mathrm{C}$ of bulk carbonates from Hole 641C. Age from Leg 103 biostratigraphic data (Shipboard Scientific Party, 1987b). 
2. Zone II: Samples $103-641 \mathrm{C}-7 \mathrm{R}-1,115-117 \mathrm{~cm}$, to $103-$ 641C-9R-3, 120-122 cm, (209.85 to $232.20 \mathrm{mbsf}$ ) have an increasing Sr content to about $350 \mathrm{ppm}$ in Sample 103-641C-8R-1, $70-72 \mathrm{~cm}$. The upper and lower boundaries of this zone correspond to negative shifts in the $\mathrm{Sr}$ content.

3. Zone III: Samples 103-641C-9R-3, $120-122 \mathrm{~cm}$, to 103$641 \mathrm{C}-15 \mathrm{R}-3,102-103 \mathrm{~cm},(232.20$ to $289.82 \mathrm{mbsf})$ continue the increase of $\mathrm{Sr}$ content to a culmination at $688 \mathrm{ppm}$, in Sample 103-641C-15R-1, 128-130 cm. Two subzones can be distinguished. The upper subzone IIIA has a slight increase in $\mathrm{Sr}$ content, and the lower subzone IIIB has a sharp increase. The boundary between these two subzones is at Sample 103-641C13R-1, 112-114 cm (267.62 mbsf).

4. Zone IV: Samples $103-641 \mathrm{C}-15 \mathrm{R}-3,102-103 \mathrm{~cm}$, to $103-$ 641C-16R-8, 55-57 cm, (289.82 to 305.05 mbsf) have Sr concentrations that remain high (between 400 and $700 \mathrm{ppm}$ ) but show great variability. Two subzones can be distinguished, the upper subzone IVA with generally decreasing $\mathrm{Sr}$ concentrations and the lower subzone IVB in which the concentrations generally increase.

\section{Magnesium}

Despite having great variability as a result of low carbonate content in some parts of this hole, the general trend of $\mathrm{Mg}$ concentration is the same as that observed for Sr. Concentrations increase from about 1300 ppm (Sample 103-641C-1R-1, 10-12 $\mathrm{cm}$ ) to $3158 \mathrm{ppm}$ (Sample 103-641C-16R-8, 55-57 cm). Shortterm fluctuations allow us to distinguish the same four geochemical zones as for Sr (Fig. 1).

\section{Manganese}

Downhole trends in Mn contents at Hole $641 \mathrm{C}$ can be divided into two sections (Fig. 1):

1. From Core 103-641C-1R to Sample 103-641C-8R-1, 70$72 \mathrm{~cm},(160-219.10 \mathrm{mbsf}) \mathrm{Mn}$ concentrations are less than 1100 ppm, with a sharp increase to $4600 \mathrm{ppm}$ between Samples 103 641C-1R-7, 115-117 cm, and 103-641C-8R-1, 70-72 cm.

2. From Samples $103-641 \mathrm{C}-8 \mathrm{R}-1,70-72 \mathrm{~cm}$, to $103-641 \mathrm{C}$ $16 \mathrm{R}-8,55-57 \mathrm{~cm},(219.10-305.05 \mathrm{mbsf})$ there is an overall decrease in Mn concentration. In detail, concentration decreases sharply to Sample 103-641C-9R-3, 120-122 cm (723 ppm), increases in Sample 103-641C-10R-1, 18-20 cm (1805 ppm), and progressively decreases to the bottom of the hole $(250 \mathrm{ppm})$.

The short-term fluctuations lead us to distinguish the same four geochemical zones as for $\mathrm{Sr}$ and $\mathrm{Mg}$.

\section{Iron}

The upper part of Hole $641 \mathrm{C}$ (above $232.20 \mathrm{mbsf}$ ) is characterized by low $\mathrm{Fe}$ content, whereas the lower part of the hole (below 232.20 mbsf) has a high Fe content (Fig. 1). As in the preceding, the four geochemical zones can be distinguished.

1. Zone I: Very low Fe contents (lower than $100 \mathrm{ppm}$ ).

2. Zone II: A slight increase in Fe concentration that reaches $500 \mathrm{ppm}$.

3. Zone III: A sharp increase in Fe content in the upper part of this zone (1500-2500 ppm) is followed by a progressive decrease to a concentration of less than $1000 \mathrm{ppm}$.

4. Zone IV: Another increase in Fe content that is followed by a slight decrease.

Based on $\mathrm{Fe} / \mathrm{Mn}$ ratios, Hole $641 \mathrm{C}$ sediments can be divided into two sections. In zones $\mathrm{I}$ and $\mathrm{II}$, the $\mathrm{Fe} / \mathrm{Mn}$ ratio is much less than 1, whereas in zones III and IV it is greater than 1 (see the following discussion).

\section{Trace Element Zonation and Biostratigraphy}

Not only are geochemical zonations of the four trace elements the same at Hole $641 \mathrm{C}$, there is also relatively good agreement between these geochemical zones and the biostratigraphy defined by Moullade et al. (this volume). The geochemical zone I/zone II boundary is close to the Aptian/Albian boundary. Zone II coincides approximately with the upper Aptian, and zone IIIA corresponds to lower Aptian. The zone IIIA/zone IIIB boundary is close to the Barremian/Aptian boundary (Fig. 1).

\section{Evolution vs. Depth at Hole 638B}

Samples studied from Hole 638B range in age from late Barremian (Sample 103-638B-21R-1, 90-92 cm) to late Valanginian (Sample 103-638B-45R-1, 95-97 cm). Lithology varies from limestone and marlstone (Subunit IIA, Barremian), to nannofossil marlstone (Subunit IIB, Hauterivian and uppermost Valanginian), and to claystone/marlstone turbidites (Subunits IIIA and IIIB, upper Valanginian). Details of the lithology can be found in the "Site 638" chapter (Shipboard Scientific Party, 1987a). In the lower part of Hole 638B (from Sample 103-638B-36R-2, 25$27 \mathrm{~cm}$ ), numerous samples were not considered in this study due to low $\mathrm{CaCO}_{3}$ content and/or the presence of dolomite or siderite.

\section{Strontium}

Sr content decreases with depth, from $598 \mathrm{ppm}$ in Sample 103-638B-21R-1, 90-92 cm, to $152 \mathrm{ppm}$ in Sample 103-638B38R-1, 17-19 cm (Fig. 2). This relationship is the opposite of that observed in Hole $641 \mathrm{C}$ (see the following discussion).

Five geochemical zones can be distinguished in Hole 638B, but the upper boundary of the lowermost zone is uncertain because of unreliable results from samples containing dolomite.

1. Zone I: From 191 to 212.20 mbsf (Samples 103-638B21R-1 90-92 cm, to 103-638B-23R-3, 90-92 cm) Sr content decreases from 598 to $282 \mathrm{ppm}$.

2. Zone II: From 212.20 to 261.10 mbsf (Samples 103-638B23R-5, 60-62 cm, to 103-638B-28R-3, 80-82 cm) the $\mathrm{Sr}$ content increases slightly to $386 \mathrm{ppm}$. A weak negative excursion at 236.65 mbsf (Sample 103-638B-25R-6, 75-77 cm) separates this zone in two subzones.

3. Zone III: From 261.10 to 298.30 mbsf (Samples 103638B-28R-6, 30-32 cm, to 104-638B-32R-2, 80-82 cm) Sr concentrations decrease from 386 to $256 \mathrm{ppm}$, and they increase at 307.60 mbsf (Sample 103-638B-33R-2, 50-52 cm).

4. Zone IV: From 307.60 to 344.80 or 353.97 mbsf Sr content decreases to about $130-150 \mathrm{ppm}$. Because of the presence of dolomite, the exact location of the lower boundary cannot be precisely defined.

5. Zone V: Below 353.97 mbsf the Sr content remains low, but the scarcity of reliable samples does not permit us to define this zone distinctly.

\section{Magnesium}

Despite being highly variable, the general trend in $\mathrm{Mg}$ content is, as for Sr, a decrease, from $2780 \mathrm{ppm}$ at $191 \mathrm{mbsf}$ to 1740 ppm at 353.97 mbsf (Fig. 2). Short-term fluctuations enable us to distinguish the same five geochemical zones as for $\mathrm{Sr}$, but zone III can be separated into three subzones by distinctive negative excursions.

As we observed in Hole $641 \mathrm{C}, \mathrm{Mg}$ and $\mathrm{Sr}$ contents covary, which permits excellent stratigraphic discrimination (see the following discussion).

\section{Manganese}

The overall trend of the Mn curve can be divided in two parts: (1) an increase in Mn content from about $278 \mathrm{ppm}$ at 191 


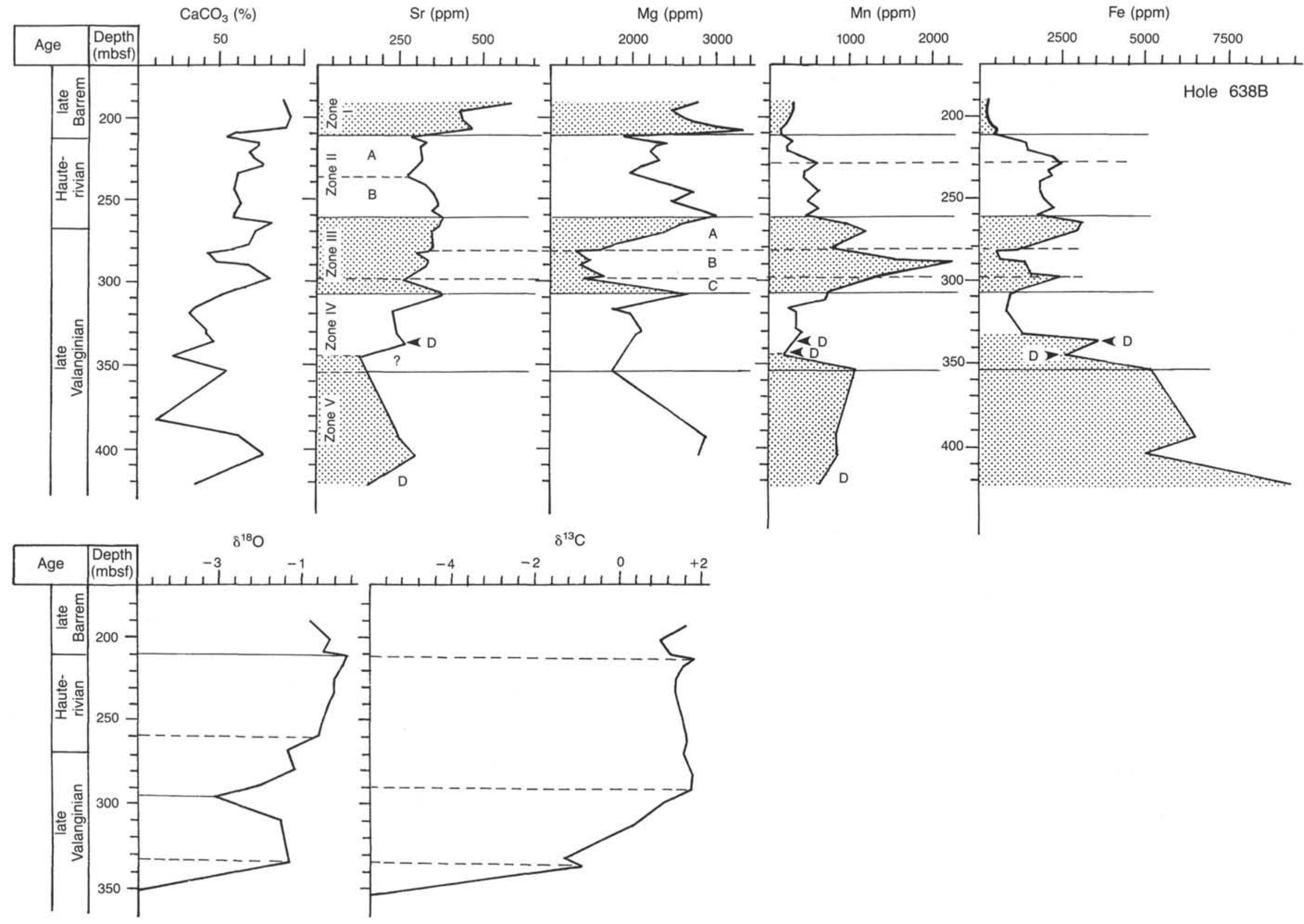


mbsf to $2272 \mathrm{ppm}$ at 289.45 mbsf (Sample 103-638B-31R-3, $115-117 \mathrm{~cm}$ ) and (2) a decrease to $156 \mathrm{ppm}$ from 289.45 to 344.80 mbsf (Fig. 2). Medium values (around $1000 \mathrm{ppm}$ ) occur again in the lower part of the hole.

As for $\mathrm{Sr}$ and $\mathrm{Mg}$, the same five geochemical zones can be distinguished: zone I with low values, zone II characterized by a slight increase in Mn, zone III with a very strong increase in Mn content, zone IV with low values, and zone $\mathrm{V}$ with medium values.

\section{Iron}

Pelagic carbonate $\mathrm{Fe}$ concentrations increase with depth in the hole from $249 \mathrm{ppm}$ (191 mbsf) to 9543 (422.45 mbsf). Zone $\mathrm{I}$ is characterized by low values, and zone II by an increase of $\mathrm{Fe}$ contents. Zone III is more complex, with medium values overall and a distinct negative excursion. Zone IV is characterized by an important increase in $\mathrm{Fe}$ content, and zone $\mathrm{V}$ has a high $\mathrm{Fe}$ content.

\section{Trace Element Zonation and Biostratigraphy}

Agreement between the geochemical and biostratigraphic zonations is not as good as for Hole 641C. The boundary between zones I and II is in good correspondence to the Barremian/ Hauterivian boundary, but the Hauterivian/Valanginian (as defined by Moullade et al., this volume) does not correspond with either the boundary of geochemical zones II and III, or the lower boundary of zone III.

\section{STABLE ISOTOPE RESULTS}

\section{Evolution vs. Depth at Hole 641C}

\section{Oxygen}

The overall trend of $\delta^{18} 0$ decreases with depth from $-0.63 \% 0$ in Sample 103-641C-6R-3, 105-107 cm (203.05 mbsf) to -2.62 in Sample 103-641C-16R-2, 105-107 cm (298.05 mbsf) (Fig. 1).

Two major breaks in the $\delta^{18} \mathrm{O}$ trend are at $253.09 \mathrm{mbsf}$ (Sample 103-641C-11R-4, 129-131 cm) and 298.05 mbsf (Sample 103-641C-16R-2, 105-107 cm). The first one corresponds to a positive excursion $(-0.49 \%)$ that separates the upper part of the hole, where $\delta^{18} \mathrm{O}$ decreases moderately, from the lower part of the hole, where it decreases sharply. The second major break is a negative shift that precedes a sharp increase of $\delta^{18} \mathrm{O}$ in the deepest part of the hole. These breaks do not coincide with the biostratigraphic boundaries; the first one occurs within the lower Aptian section and the second one within the upper Barremian section.

\section{Carbon}

In the upper part of the hole, $\delta^{13} \mathrm{C}$ decreases sharply from high values $(+3.71 \%$ in Sample 103-641C-6R-3, 105-107 cm) that are characteristic of the Aptian/Albian boundary (Renard, 1985 ) to $+1.36 \%$ (232.20 mbsf; Sample 103-641C-9R-3, 120-122 $\mathrm{cm}$ ) (Fig. 1). Below $232.20 \mathrm{mbsf}, \delta^{13} \mathrm{C}$ increases slightly to $+2.06 \%$ in Sample 103-641C-16R-3, 105-107 cm (299.95 mbsf). Within this slight increase is a minor negative excursion in Core 103641C-14R ( 276.98 to $281.65 \mathrm{mbsf}$ ). An important negative shift occurs in the deepest part of Hole 641C in Sample 103-641C$16 \mathrm{R}-6,48-50 \mathrm{~cm}(+0.22 \% 0)$. Such a negative shift has already been documented in various other uppermost Barremian sites (Schuber, 1984; Renard, 1985). Thus, the cogency of $\delta^{13} \mathrm{C}$ as a stratigraphic indicator (Scholle and Arthur, 1980; Letolle and Renard, 1980; Renard, 1985, 1986b; Shackleton, 1986; Shackleton and Hall, 1984; Weissert et al., 1979, 1985) is further confirmed at this hole. A major isotopic break is at the upper/ lower Aptian contact, and a second one is within the uppermost Barremian. The uppermost Barremian negative shift could be a marker, which is better defined at sites with a more extended Barremian section.

\section{Evolution vs. Depth at Holes 638B and 638C}

\section{Oxygen}

Values of $\delta^{18} \mathrm{O}$ increase slightly from $191 \mathrm{mbsf}(-0.78 \% 0)$ to 212.20 mbsf ( $-0.13 \%$ ) (Fig. 2). This part of the curve generally corresponds to the trace element geochemical zone I described previously. Below $212.20 \mathrm{mbsf}, \delta^{18} \mathrm{O}$ decreases weakly to 261.10 mbsf $(-0.54 \%)$; this interval corresponds roughly to trace element zone II. A sharp negative excursion occurs from 261.10 to 298.30 mbsf ( $-3.08 \%$ ), which generally corresponds to geochemical zone III. The $\delta^{18} \mathrm{O}$ curve shows another increase $(-1.22 \%$ at $336.25 \mathrm{mbsf}$ ), with a high negative value at $344.80 \mathrm{mbsf}$ $(-4.88 \%)$. In the lower part of the hole, mixing of calcite and dolomite in the samples has resulted in more complex data for which it is difficult to identify a general trend.

\section{Carbon}

A minor negative excursion occurs between 191 and 212.20 mbsf $(+0.97 \% 0$ at $200.70 \mathrm{mbsf})$, below which $\delta^{13} \mathrm{C}$ remains generally constant, with only a slight increase between 215.90 $(+1.55 \%)$ and $289.45 \mathrm{mbsf}(+1.78 \%$ ) (Fig. 2). In the lower part of the hole the carbon isotope ratio decreases drastically to $-6.01 \%$ at 353.97 mbsf. As for $\delta^{18} \mathrm{O}$, we can observe a large variability in $\delta^{13} \mathrm{C}$ in the Hole $638 \mathrm{C}$ samples (from $+2.25 \%$ to $-3.97 \%$; sideritic samples show positive values whereas the other samples have negative $\delta^{13} \mathrm{C}$ ).

\section{DISCUSSION}

\section{Trace Elements}

Because the majority of chemical elements are not directly precipitated from seawater, they are removed from the ocean by various processes of coprecipitation (coprecipitation sensu stricto, adsorption, and occlusion) in major minerals such as carbonates. Whatever the mechanism (for details see Renard, 1985), a relationship exists between the trace element content of a carbonate and the concentration of this element in the water in which precipitation takes place. For example, this relationship for Sr can be written (Holland et al., 1963)

$$
(\mathrm{Sr} / \mathrm{Ca})_{\text {carbonate }}=\mathrm{K}_{\mathrm{Sr}}(\mathrm{Sr} / \mathrm{Ca})_{\text {water }} \text {, }
$$

where $\mathrm{K}$ is the distribution coefficient.

The potential thus exists to derive a seawater chemical parameter through a chemical parameter of carbonate. However, the actual distribution coefficient depends on numerous factors, including the mineralogical nature of the carbonate, the temperature of precipitation, the crystallization rates, and the biological fractionation.

Despite these variables, biogenic carbonates record the physical-chemical variations in their environment. Pelagic carbonates provide the most suitable material for such research because (1) the restricted number of $\mathrm{CaCO}_{3}$-producing organisms (mainly planktonic foraminifers and nannofossils) limits biological fractionation problems (Renard, 1985), (2) all these organisms produce low-Mg calcite (Milliman, 1974), and (3) diagenetic perturbations are minimized in the pelagic realm (Renard, 1985). In Hole 641C, there are numerous layers containing displaced shallow-water benthic fossils; some of this material may have been included in samples used in the study.

Because burial diagenesis leads to a loss in $\mathrm{Sr}$ (Veizer, 1977, 1983; Baker et al., 1982; Renard, 1979; Renard et al., 1979a, $1979 b$ ), the generally positive downhole trend in $\mathrm{Sr}$ content observed at Hole $641 \mathrm{C}$ clearly shows that $\mathrm{Sr}$ concentrations at this 
hole are not controlled mainly by diagenesis. This suggests that the $\mathrm{Sr}$ content of pelagic carbonate reflects, at least partially, seawater $\mathrm{Sr} / \mathrm{Ca}$ fluctuations. In Hole $638 \mathrm{~B}, \mathrm{Sr}$ content decreases with depth. That these two holes, with approximately the same sediment load, have opposing relationships of $\mathrm{Sr}$ content with depth also argues against late burial diagenesis having a significant influence on the geochemistry of $\mathrm{Sr}$ in pelagic carbonates. The comparison of sediment geochemistry from Holes 638B and $641 \mathrm{C}$ clearly demonstrates that the evolution of pelagic carbonate $\mathrm{Sr}$ content cannot be modeled as a simple loss of $\mathrm{Sr}$ through time. This is also confirmed by the positive relationship between $\mathrm{Sr}$ and $\mathrm{Mg}$ contents observed in Holes 641C (Fig. 3) and 638B (Fig. 4). These $\mathrm{Sr}-\mathrm{Mg}$ correlation graphs permit a good stratigraphic discrimination of the samples. A positive relationship is typical of sediments deposited during the Early Cretaceous, one of the few periods for which $\mathrm{Sr}$ and $\mathrm{Mg}$ pelagic carbonate content curves fluctuate in the same way. For most of the last 140 m.y., $\mathrm{Sr}$ and $\mathrm{Mg}$ contents have varied in opposite directions (Renard, 1985) (Fig. 5).

The behavior of Mn during sedimentation is more intricate than that of $\mathrm{Sr}$ and $\mathrm{Mg}$ because two phenomena can occur. First, there can be variations in the supply of Mn (continental or hydrothermal). Second, the oxygen content of the environment can vary. In reducing environments Mn coprecipitates with $\mathrm{CaCO}_{3}$; in oxidizing environments $\mathrm{Mn}$ bi-oxides can precipitate. Therefore, reducing environments lead to formation of $\mathrm{Mn}$ poor carbonates whereas oxidizing environments lead to formation of Mn-rich sediments.

Although the Mn content of pelagic sediments thus reflects these two phenomena, the most important control is the fluctuation of hydrothermal activity (Edmond et al., 1979). We postulate that $\mathrm{Fe} / \mathrm{Mn}$ ratios greater than 1 are characteristic of a continental detrital supply (soluble) and that $\mathrm{Fe} / \mathrm{Mn}$ ratios less than 1 are characteristic of a submarine hydrothermal supply. Thus, geochemical zones I and II (upper Aptian-Albian) in Hole $641 \mathrm{C}$ were influenced mainly by hydrothermal activity, and zones III and IV (Barremian-lower Aptian) were controlled by the continental supply (Fig. 6). This relationship has been observed in sediments of the same age from Holes 398D (Vigo Seamount, DSDP Leg 47B; Renard et al., 1979a) and 400A (northern Bay of Biscay, DSDP Leg 48; Renard et al., 1979b). In Hole $638 \mathrm{~B}$, most of the samples are influenced by the continental supply (Fig. 7). Only a few samples of Hauterivian age (Cores 103-638B-30R and 103-638B-31R) have $\mathrm{Mn} / \mathrm{Fe}$ ratios larger than 1 , which could reflect a weak hydrothermal influence.

\section{Stable Isotopes}

The utility of $\delta^{18} \mathrm{O}$ data from bulk carbonates is controversial. For example, the observed overall decrease in $\delta^{18} \mathrm{O}$ (from $+0.63 \%$ to $-2.62 \%$ ) with depth in Hole $641 \mathrm{C}$ (Fig. 1) could be interpreted in terms of increasing diagenesis with depth. However, several observations argue against such interpretation. First, the increase in the amount of sediment overburden at Hole 641C is small (about $100 \mathrm{~m}$, between Cores 103-641C-6R and 103-641C-16R). Second, $\delta^{18} \mathrm{O}$ becomes heavier in the deepest part of the hole (from $-2.62 \%$ in Section 103-641C-16R-3 to $-0.87 \%$ and $-1.95 \%$ in Sections $103-641 \mathrm{C}-16 \mathrm{R}-6$ and $103-$ 641C-16R-8). Finally, the inverse correlation that exists between the oxygen isotope ratio and $\mathrm{Sr}$ content (Fig. 8) is inconsistent with a diagenetic explanation.

These facts suggest that the main part of the bulk pelagic carbonate $\delta^{18} \mathrm{O}$ evolution record represents the paleoceanographic conditions (temperature and/or seawater $\delta^{18} \mathrm{O}$ variations). This observation is in agreement with observations of Clauser (1987) on Upper Cretaceous sediments from various European pelagic outcrops and DSDP sites.

The more complex $\delta^{18} \mathrm{O}$ data from Site 638 exhibit a sharp negative excursion (to $-3.08 \%$ ) from 261.10 to $298.30 \mathrm{mbsf}$ (Fig. 2). Similar negative values have been found in Hauterivian sediments from Hole $391 \mathrm{C}$ by Letolle et al. (1978) and Schuber (1984). A very negative value $(-4.88 \%)$ occurs at $344.8 \mathrm{mbsf}$.

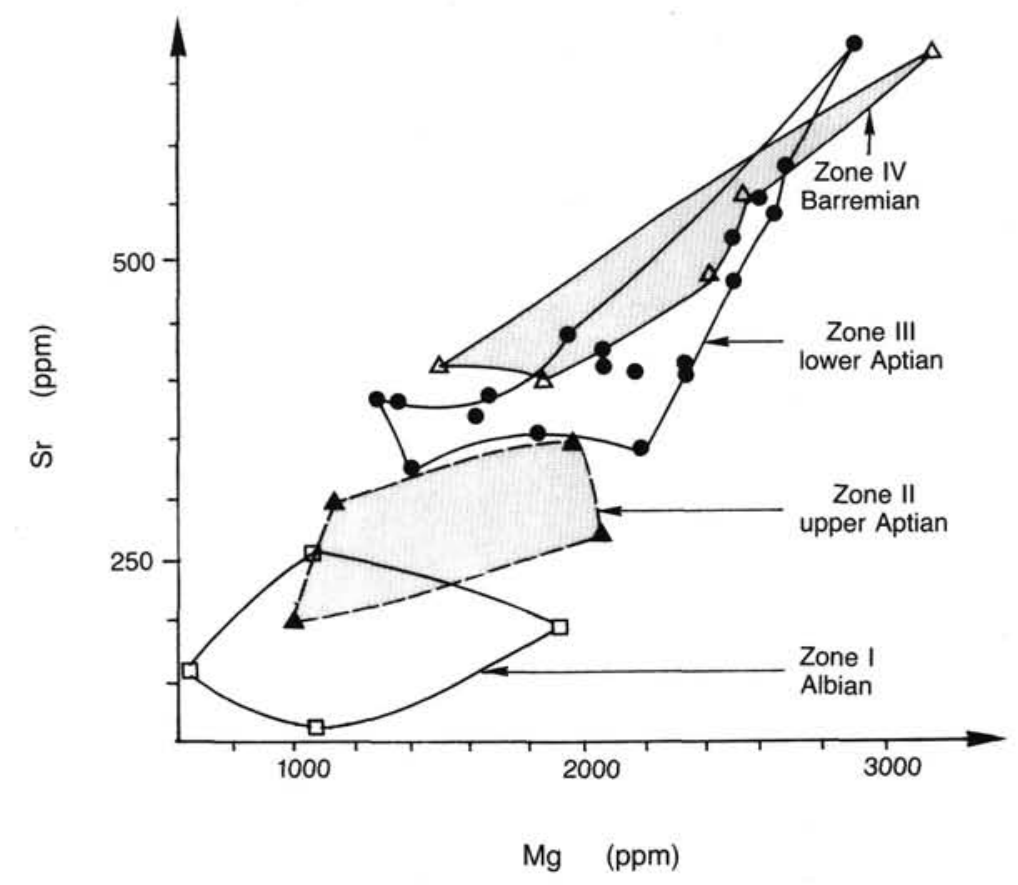

Figure 3. Relationship between $\mathrm{Sr}$ and $\mathrm{Mg}$ contents of carbonates from Hole 641C. This positive correlation seems to be characteristic only of pelagic sediments of Early Cretaceous age. Geochemical zones I-IV described in text. 


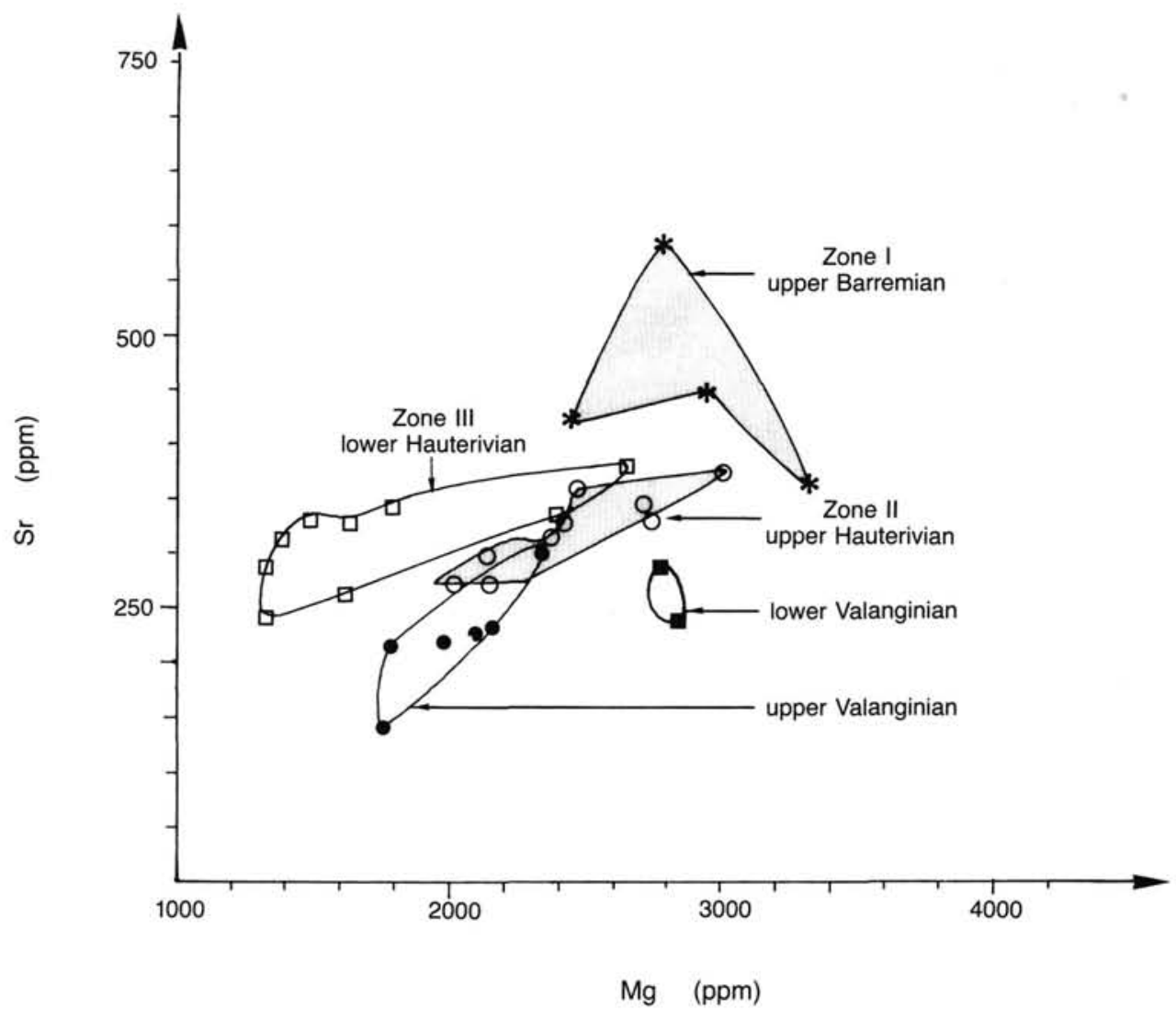

Figure 4. Relationship between $\mathrm{Sr}$ and $\mathrm{Mg}$ contents of carbonates from Hole 638B. Geochemical zones described in text.

Values of about - 5\% have also been reported in Hole $391 \mathrm{C}$ in upper Valanginan sediments by Letolle et al. (1978), with an interpretation as a climatic event (Schuber, 1984). For Site 638, the linkage with a very negative $\delta^{13} \mathrm{C}(-6.01 \%$, as opposed to a slightly positive $\delta^{13} \mathrm{C}$ in Hole $391 \mathrm{C}$ ) leads us to interpret this value in one of two ways: either as a result of the supply of material from restricted basins with continental water influences during sedimentation and/or diagenesis (this agrees with the turbiditic nature of the sediments and the presence of terrestrial plant debris; see "Site 638" chapter; Shipboard Scientific Party, 1987a) or as a consequence of a hydrothermal influence through the sediments.

The relationship between $\delta^{18} \mathrm{O}$ and $\mathrm{Sr}$ content casts light upon this problem (Fig. 9). For Aptian to upper Hauterivian samples (from 191 to $261.10 \mathrm{mbsf}$; i.e., trace element geochemical zones I and II), there is a negative correlation between the two markers ( $\mathrm{Sr}$ content increases as $\delta^{18} \mathrm{O}$ decreases). This confirms that, at least for the upper part of Hole 638B (as in Hole 641C), $\mathrm{Sr}$ content and $\delta^{18} \mathrm{O}$ data cannot be interpreted in terms of diagenesis.

In the lower part of the hole, the data are more complex. For lower Hauterivian to upper Valanginian samples, the correlation becomes positive ( $\mathrm{Sr}$ content and $\delta^{18} \mathrm{O}$ both decrease). Moreover, the plotted data from the lower part of Hole $638 \mathrm{~B}$ and from Hole $638 \mathrm{C}$ can be divided into two groups (Fig. 9), one that corresponds to the samples with dolomite and one to the samples without. For the same $\mathrm{Sr}$ content, the difference in $\delta^{18} \mathrm{O}$ is about $+1.75 \%$. The higher values of $\delta^{18} \mathrm{O}$ for samples with dolomite, as opposed to pure calcitic samples, agree with the known relationship of fractionation between dolomite and calcite $\left(\delta_{\text {dolomite }}-\delta_{\text {calcite }}\right.$ ranges from about $3 \%$ to $6 \%$ at $25^{\circ} \mathrm{C}$; Land, 1980). But because the dolomite content of the studied samples is low (from $0 \%$ to $25 \%$ ), the explanation cannot involve a simple mixing of two mineralogical phases. The presence of $10 \%$ dolomite (as in Samples 103-638B-35R-5, 112-114 $\mathrm{cm}$, and 103-638B-3R, $25-27 \mathrm{~cm}$ ) could bring an increase of only about $+0.3 \%$ to $+0.6 \%$ in $\delta^{18} \mathrm{O}$ and not the observed charge of $1.75 \%$. This suggests that the calcite from these different samples is not of the same origin. The occurrence of high-temperature diagenetic calcite (and/or related low isotopic ratio interstitial water) is probable in Samples 103-638B-38R-5, $112-114 \mathrm{~cm},\left(\delta^{18} \mathrm{O}=-4.88 \%\right)$ and $103-638 \mathrm{C}-10 \mathrm{R}, \mathrm{CC}(14-16$ $\mathrm{cm})\left(\delta^{18} \mathrm{O}=-6.92 \%\right)$. We also note that the oxygen data from Hole $638 \mathrm{C}$ show high variability (from $+1.89 \%$ to $-6.92 \% 0$ ), with the lone positive value related to a sideritic sample.

Bulk carbonate $\delta^{18} \mathrm{O}$ values from Valanginian samples from these two sites agree with those reported by Loreau and Cros (this volume) from pure mineralogical phases $\left(\delta^{18} \mathrm{O}\right.$ between $+3.08 \%$ and $-10.3 \%$ ). Negative $\delta^{13} \mathrm{C}$ values, which are on the order of those found by Kelts and McKenzie (1982) in DSDP Sites 475 to 480 (Gulf of California), lead us to think that at least part of the dolomite and associated calcite from the bottom of Holes $638 \mathrm{~B}$ and $638 \mathrm{C}$ could be diagenetic, having originated from the degradation of organic matter in anoxic porewater conditions.

\section{OCEAN CHEMISTRY FLUCTUATIONS DURING THE EARLY CRETACEOUS}

Although there are some stratigraphic problems, the sediments recovered during Leg 103 provide a good record of the geochemistry of Lower Cretaceous pelagic carbonates, which allows us to reconstruct the chemistry of the ocean for this period. Using the time scale from Odin (1982), Leg 103 trace element data are plotted vs. time in Figure 10. We note that there is 


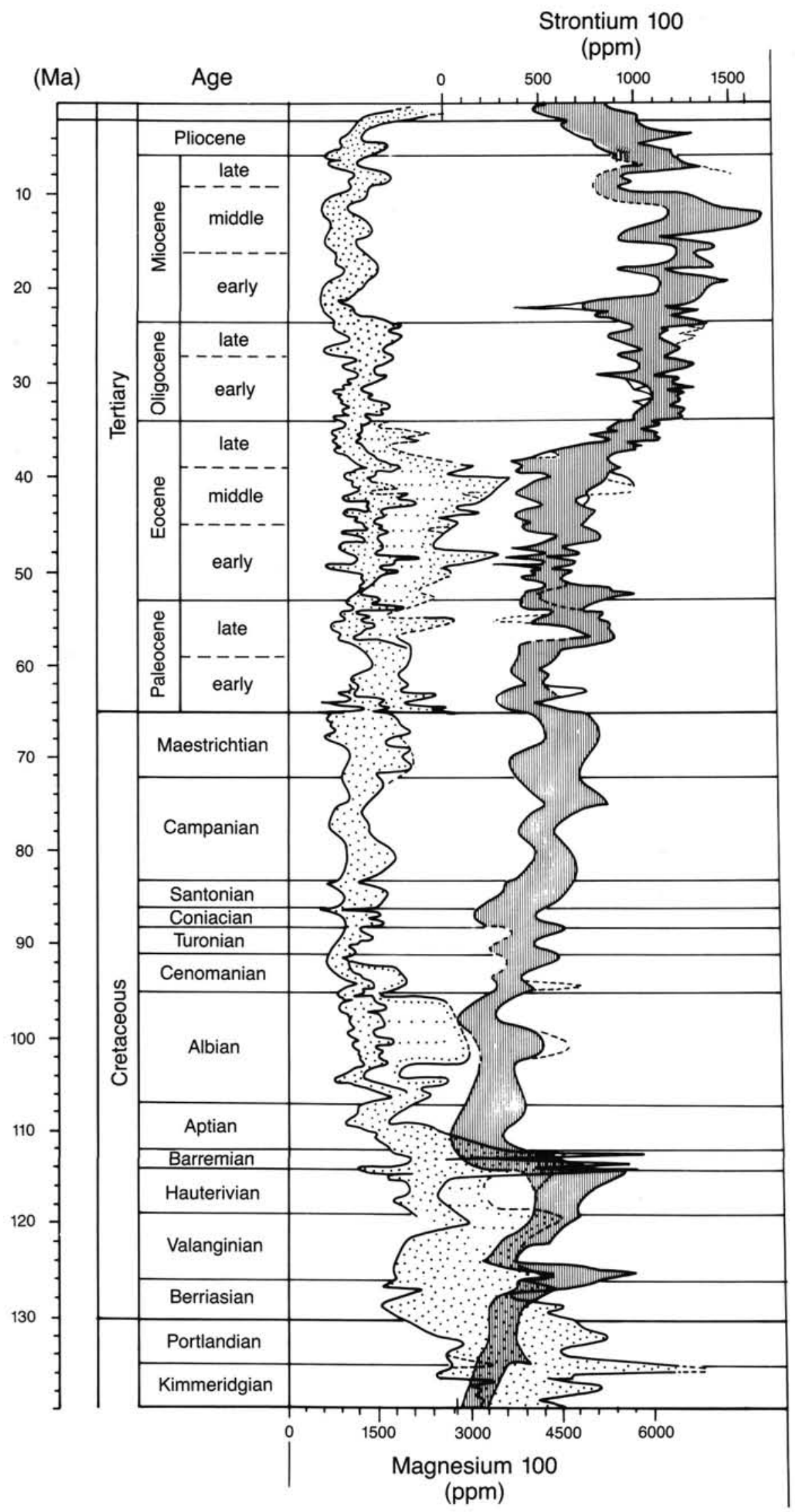

Figure 5. Evolution through time (since the Late Jurrassic) of $\mathrm{Sr}$ (shaded curve) and $\mathrm{Mg}$ contents (dotted curve) of pelagic carbonates. These curves are deduced from the analysis of 1500 samples from various DSDP sites and land outcrops (Renard, 1985). The high and low values define the interval of fluctuation for each element. 


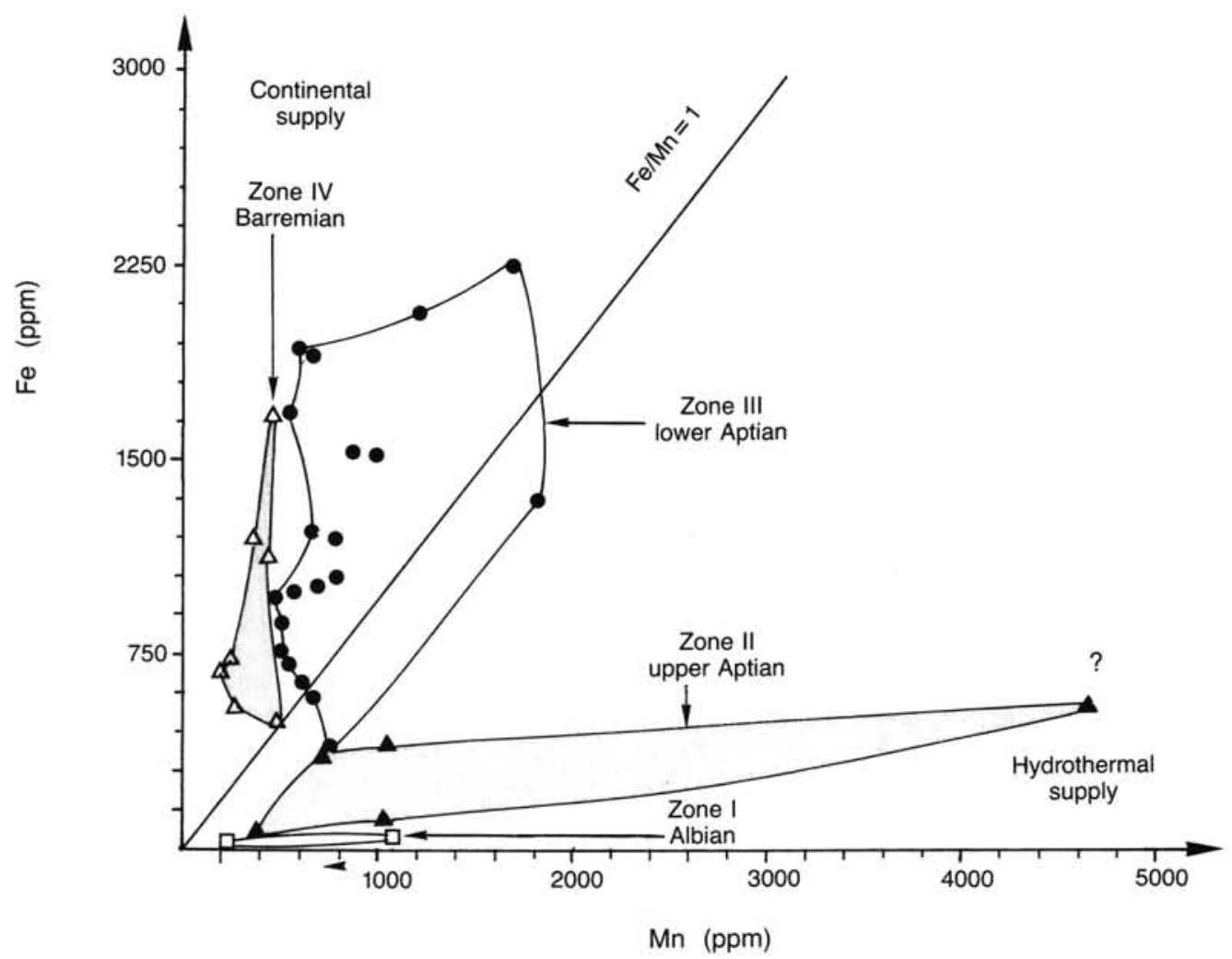

Figure 6. Relationship between Mn and Fe contents of carbonates from Hole 641C. Geochemical zones described in text.

excellent concordance between the curves from Holes $641 \mathrm{C}$ and $638 \mathrm{~B}$. Because of the presence of dolomite and anoxic pore-water diagenesis in the lower part of Hole 638B, Valanginian sediments cannot be used as reliable recorders of paleoceanographic conditions.

\section{Trace Elements}

\section{Strontium}

From the lower Hauterivian to Barremian section, the $\mathrm{Sr}$ content of pelagic carbonates increases, at first slightly in the Hauterivian and then drastically in the lower Barremian. In contrast, $\mathrm{Sr}$ concentrations decrease, from the Barremian/Aptian contact to the Albian. This suggests that a seawater $\mathrm{Sr} / \mathrm{Ca}$ variation occurred during the Early Cretaceous. The ratio is moderate in the Hauterivian (with a small decrease corresponding to between 115.5- and 114-m.y.-old sediment), high in the Barremian (with high variability in the upper part of this stage), and decreased in the Aptian, whereas it remains low in the Albian.

This pattern confirms the previous results of Renard (1985, 1986b) although the $\mathrm{Sr} / \mathrm{Ca}$ ratio decrease observed for the Aptian is more progressive than previously thought. Seawater $\mathrm{Sr} / \mathrm{Ca}$ fluctuations are mainly controlled by seawater $\mathrm{Ca}$ concentration fluctuations, which depend on hydrothermal activity at midoceanic ridges and on variations in the magnitude of carbonate sedimentation on the continental shelves.

It appears that from the early Hauterivian to the latest Barremian, seawater $\mathrm{Ca}$ content decreased, leading to large seawater $\mathrm{Sr} / \mathrm{Ca}$ ratios. Kazmierczak et al. (1985) used paleontological data and Renard (1986a) used geochemical data to postulate that the ocean is periodically "poisoned" by $\mathrm{Ca}$ and that carbonate sedimentation plays a role in "detoxification." The evolution observed for the Hauterivian-Barremian corresponds to such a detoxification interval. Whatever the mechanisms responsible, the Barremian appears to have been a period of chemical crisis that may have separated two chemical modes of the ocean: (1) an old ocean in which $\mathrm{Ca}$ fluctuations are mainly regulated by netritic sedimentation and (2) the modern ocean, beginning in the late Barremian, in which Ca fluctuations are regulated by pelagic sedimentation.

We also note the high stratigraphic resolution of pelagic carbonate $\mathrm{Sr}$ concentrations. Not only are all stage boundaries obvious on the $\mathrm{Sr}$ curve, but also, smaller stratigraphic units can be distinguished on the basis of variations in $\mathrm{Sr}$ content (e.g., the upper Hauterivian) or from breaks in the slope of the curve (e.g., in the lower Aptian).

\section{Magnesium}

For the middle Hauterivian (117 Ma) to the upper Barremian, pelagic carbonate $\mathrm{Mg}$ content remains high (between 2000 and $3000 \mathrm{ppm}$ ). It is difficult to know if the low content in the lower Hauterivian is real or if it is an artifact due to anoxic pore-water diagenesis. Data from the previous work of Renard (1985) do not permit resolution of this uncertainty, but Schuber (1984) reported a similar decrease at Hole 391C. For the upper Barremian to the Albian, $\mathrm{Mg}$ content decreases to concentrations of less than $2000 \mathrm{ppm}$. This state of low $\mathrm{Mg}$ content continues to the Recent (Fig. 5). The Barremian appears again as a chemical crisis period. Before it, seawater $\mathrm{Mg} / \mathrm{Ca}$ ratios were high; after it, ratios were low.

Fluctuation in the $\mathrm{Mg} / \mathrm{Ca}$ ratio in seawater is an important observation related to carbonate sedimentation because seawater $\mathrm{Mg} / \mathrm{Ca}$ is (along with atmospheric $\mathrm{CO}_{2}$ ) the main factor involved in regulating the mineralogical nature of inorganic $\mathrm{CaCO}_{3}$ (Sandberg, 1975; MacKenzie and Pigott, 1981; Wilkinson and Given, 1986). High seawater $\mathrm{Mg} / \mathrm{Ca}$ ratios favor the formation of aragonite whereas low $\mathrm{Mg} / \mathrm{Ca}$ ratios favor the formation of 


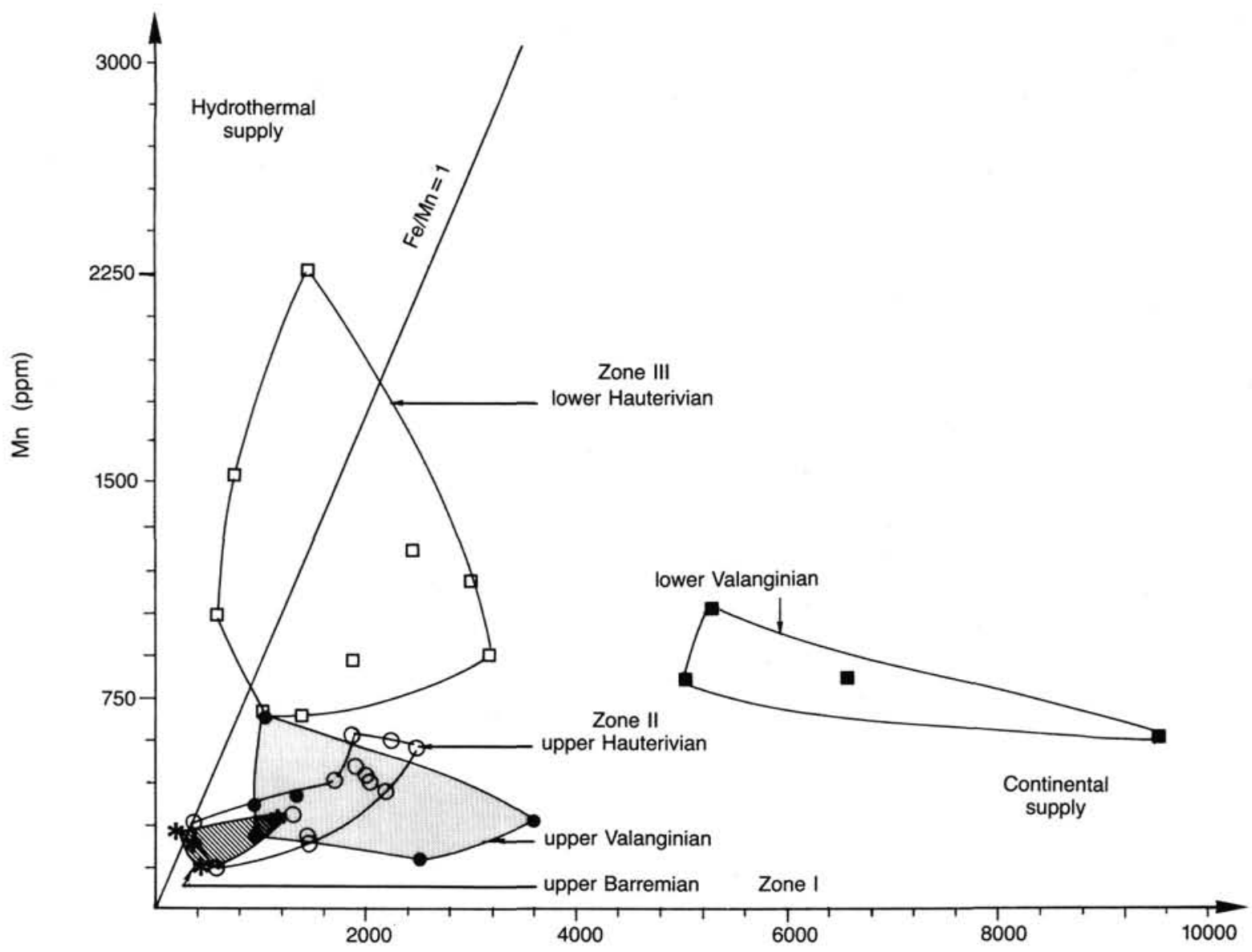

$\mathrm{Fe}(\mathrm{ppm})$

Figure 7. Relationship between $\mathrm{Mn}$ and Fe contents of carbonates from Hole 638B. Geochemical zones described in text.

calcite, although new experimental data from Burton and Walter (1987) show that calcite growth is principally favored by low sulfate content. For biogenic $\mathrm{CaCO}_{3}$, regulation by seawater chemical composition is, without doubt, not as important, though we think that seawater chemistry led to the development of the biological groups that made the particular mineralogical form for their tests. Furthermore, we note that carbonate sedimentation was mainly neritic (and consequently aragonitic, with a great development of reefal and parareefal constructions) during the Late Jurassic and Early Cretaceous when seawater $\mathrm{Mg}$ / $\mathrm{Ca}$ was high. On the contrary, pelagic carbonate sedimentation became dominant (and consequently calcitic) since the Albian, when seawater $\mathrm{Mg} / \mathrm{Ca}$ was lowered.

\section{Manganese}

For the lower Hauterivian to the Barremian, pelagic carbonate Mn content greatly decreases. As stated previously, the relatively high values for the lower Hauterivian could reflect the beginning of a first phase of hydrothermal activity (very low values for the upper Valanginian could be the result of diagenesis in anoxic pore-water conditions). For the Barremian to the upper Aptian, Mn concentrations increase, and the upper Aptian shows a very high content reflecting intense hydrothermal activity. Because of the decrease in supply and the reducing conditions of the ocean, $\mathrm{Mn}$ content is again low within the lower $\mathrm{Al}$ bian.
Iron

For the lower Valanginian to the lower Barremian, Fe content is greatly decreased. This corresponds to a decreased soluble supply from the continent. In the upper Barremian and the lower Aptian, Fe concentrations of pelagic carbonates are slightly increased. We think that this reflects (as with $\mathrm{Mn}$ ) an increase in hydrothermal activity at the rift axis or oceanic ridge. From the upper Albian, Fe concentrations remain low and as Mn content is higher, which suggests that hydrothermal Fe (which would precipitate before $\mathrm{Mn}$ ) did not reach the site location while the more soluble Mn was available.

\section{Stable Isotopes (Fig. 11)}

\section{Oxygen}

In the lowermost Hauterivian, it is difficult to distinguish the roles played by diagenesis and by climatic change in the $\delta^{18} \mathrm{O}$ trends. We interpret a slight cooling of the climate for the late Hauterivian, and from the latest Hauterivian to the beginning of the late Barremian we infer a rapid warming (about $9^{\circ} \mathrm{C}$ in $1.5 \mathrm{~m} . \mathrm{y}$.), if all the $\delta^{18} \mathrm{O}$ variation is interpreted in terms of temperature. During the late Barremian, Aptian, and earliest Albian, temperature would have decreased again, but only to a level warmer than during the Hauterivian. Thus, the Barremian is not only a critical period for ocean chemistry but it is also a period of intense climatic fluctuations. 


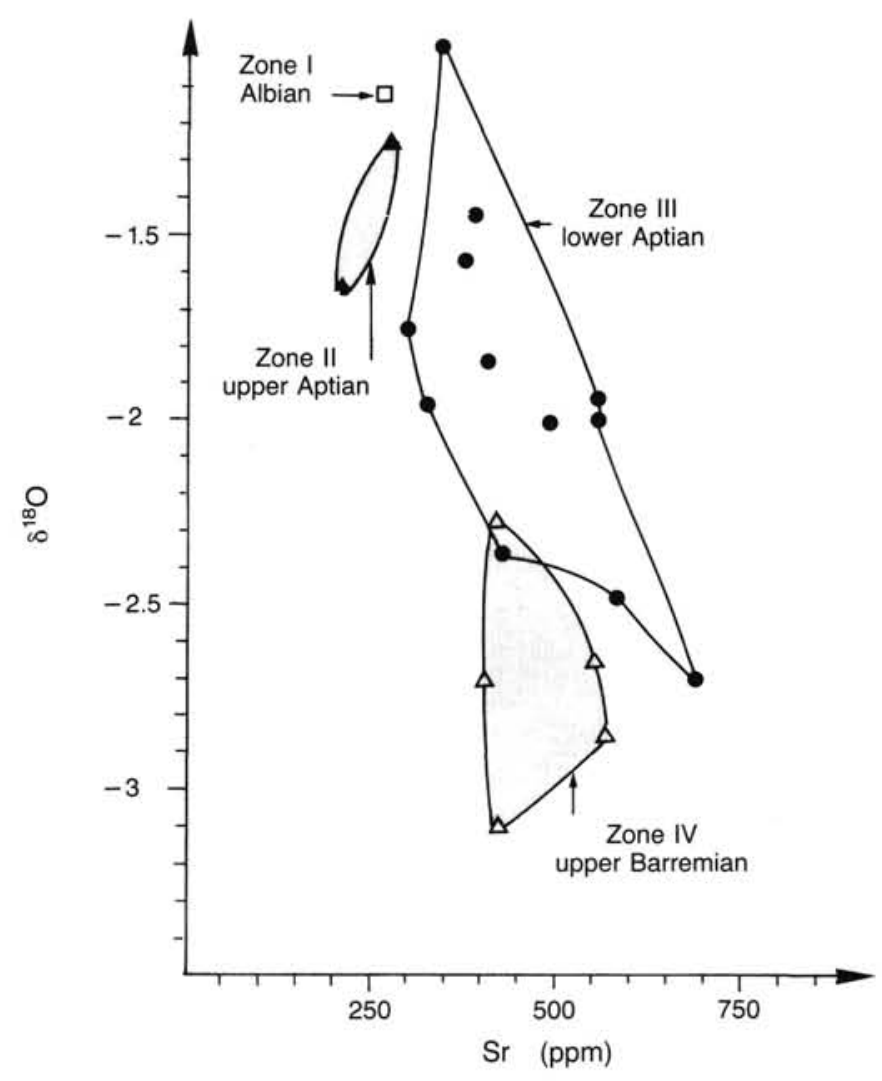

Figure 8. Relationship between $\mathrm{Sr}$ content and $\delta^{18} \mathrm{O}$ of bulk carbonates from Hole $641 \mathrm{C}$. This negative correlation is inconsistent with a diagenetic explanation of $\mathrm{Sr}$ and oxygen contents of bulk pelagic carbonates. Geochemical zones described in text.

\section{Carbon}

Values of $\delta^{13} \mathrm{C}$ are generally stable from the upper part of the lower Hauterivian to the lower Aptian. Yet, we can observe a negative excursion within the lower Barremian followed by an increase within the upper Barremian. These fluctuations seem to be controlled by organic-matter production, which is linked with sea-level changes (Scholle and Arthur, 1980; Renard, 1985). Related to anoxic conditions in the ocean during the late Aptian and Albian, $\delta^{13} \mathrm{C}$ greatly increased to reach the highest values observed for the last 140 m.y.

\section{CONCLUSIONS}

Chemical analysis of Leg 103 sediments suggests that diagenesis has played a minor role in the geochemistry of the pelagic carbonate and that a major chemical change occurred in the ocean during the Barremian. The principal Early Cretaceous chemical events recorded by Leg 103 sediments and potential paleoenvironmental events deduced from the data are summarized in Figure 12.

From the Valanginian to the Albian, the $\mathrm{CaCO}_{3}$ sedimentation budget is strongly modified. Neritic sedimentation greatly decreased while pelagic sedimentation increased; this change was concomitant with a change in ocean chemistry. Up to the Barremian, aragonite was the $\mathrm{CaCO}_{3}$ mineral form preferentially produced, but from the Aptian-Albian it is replaced by calcite (as deduced from the $\mathrm{Sr}$ and $\mathrm{Mg}$ curves).

From the early Hauterivian to the earliest Albian the sea level rose eustatically, although a rapid down and up fluctuation seems to have occurred during the Barremian (from $\delta^{13} \mathrm{C}$ and $\mathrm{Sr}$ curves).

The climate cooled slightly during the Hauterivian, abruptly warmed during the Barremian, and cooled again during the Aptian (from the $\delta^{18} \mathrm{O}$ curve).

Soluble supply from the continent decreased greatly during the Valanginian-early Hauterivian while oceanic hydrothermal

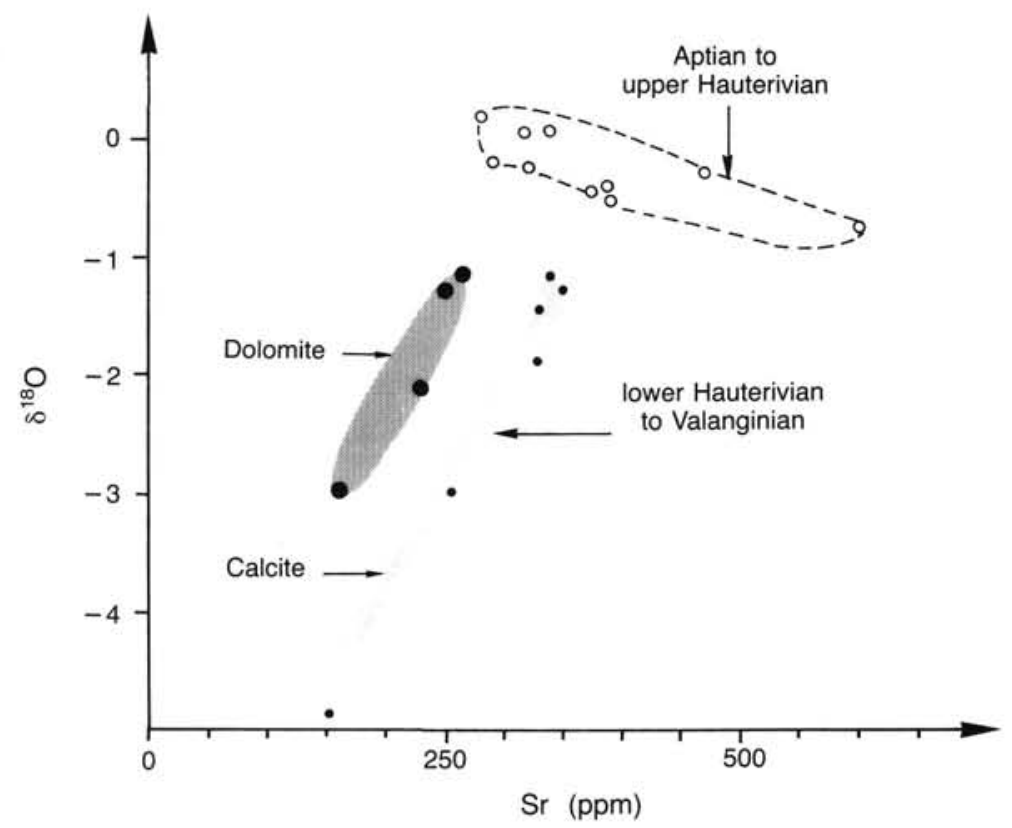

Figure 9. Relationship between $\mathrm{Sr}$ content and $\delta^{18} \mathrm{O}$ of bulk carbonates from Hole 638B. The correlation is negative for Aptian to upper Hauterivian sediments and positive for lower Hauterivian to Valanginian sediments. Note the difference between pure calcite samples and samples with dolomite present. 
TRACE ELEMENTS AND ISOTOPES IN CRETACEOUS CARBONATES

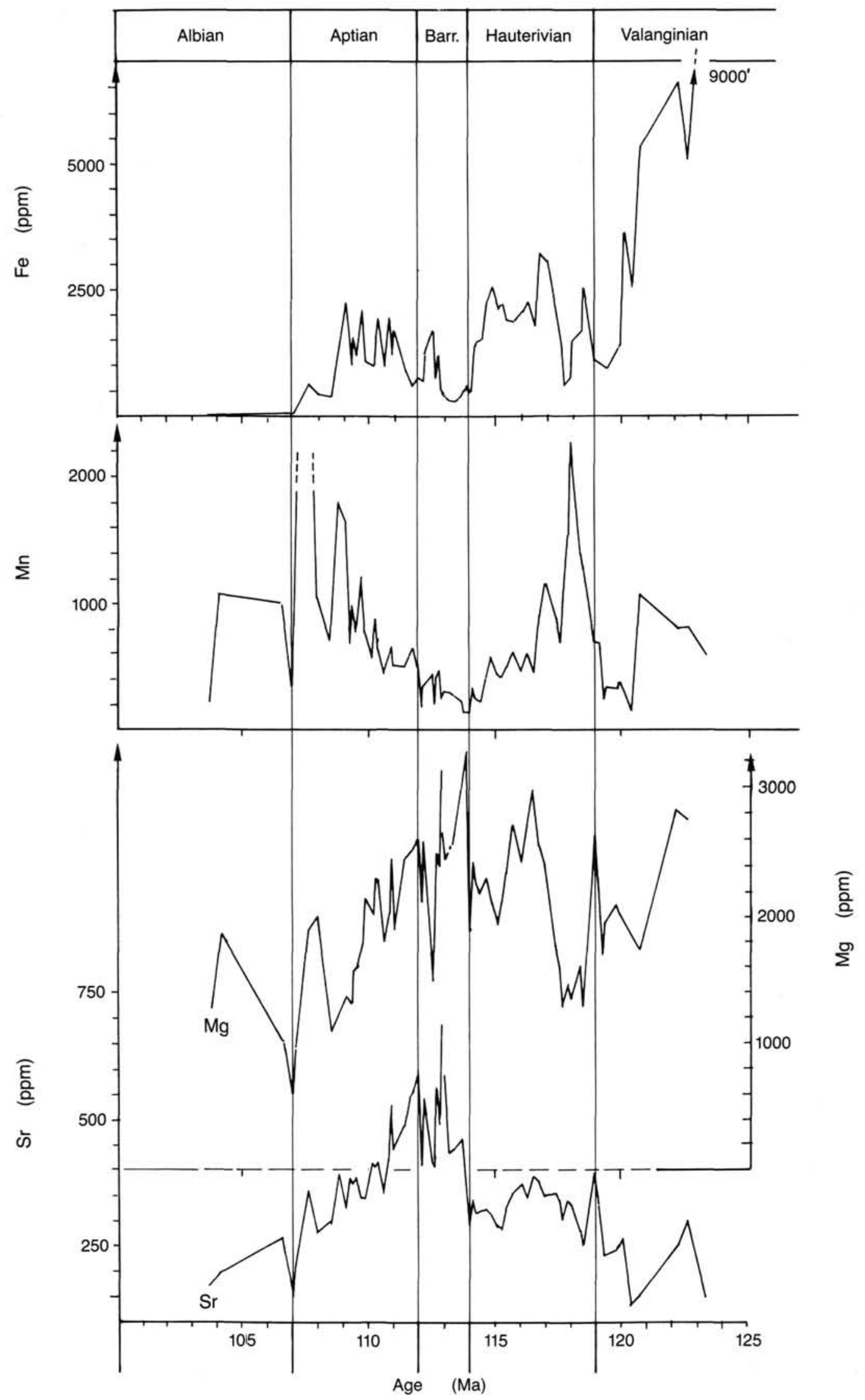

Figure 10. Evolution through time of trace element contents of pelagic carbonates recovered in Hole 638B (Valanginian to Barremian) and $641 \mathrm{C}$ (Barremian to Albian). 


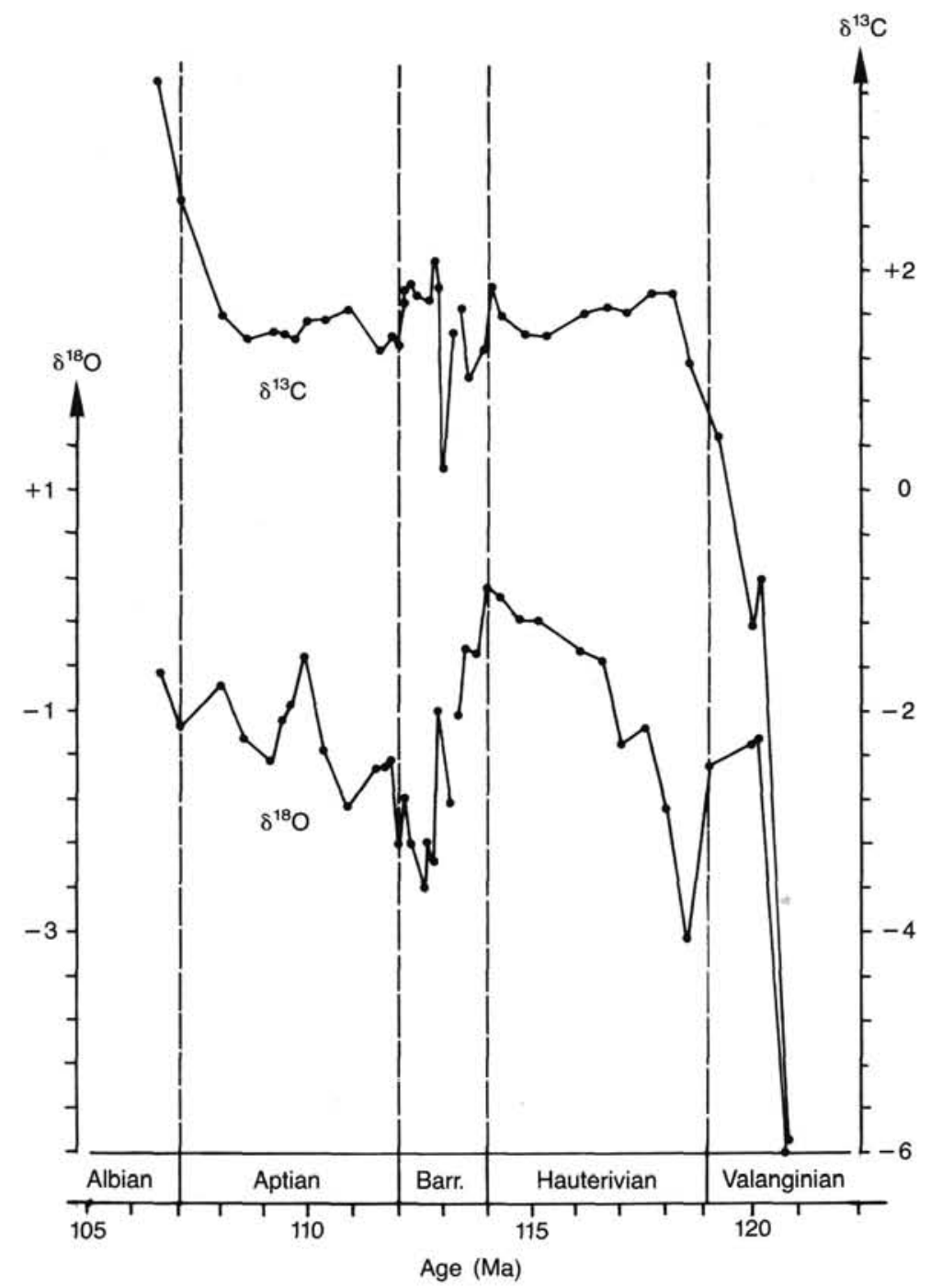

Figure 11. Evolution through time of $\delta^{18} \mathrm{O}$ and $\delta^{13} \mathrm{C}$ of bulk pelagic carbonates recovered in Holes 638B (Valanginian to Barremian) and 641C (Barremian to Albian).

supply increased. Two main phases of hydrothermal activity on the regional mid-ocean ridge system seem to have occurred during the early Hauterivian and during the late Aptian (from $\mathrm{Fe}$ and Mn curves).

Because these conclusions are deduced from geochemical data only, the next step will be to test this scenario by comparison with other geological information, which will be undertaken in a later study.

\section{ACKNOWLEDGMENTS}

Many thanks are due to Dr. André Mariotti for access to his mass spectrometer. We are also grateful to Jan Veizer (Ottawa University) and one anonymous reviewer for their constructive criticisms and their help in the English translation. Funds for this research were provided by U.P.M.C. Paris and by the French C.N.R.S. through ATP G.G.O. This work is a contribution CNRS-INSU-DBT, "Message sédimentaire."

\section{REFERENCES}

Baker, P. A., Gieskes, J. M., and Elderfield, H., 1982. Diagenesis of carbonates in deep-sea sediments. Evidence from $\mathrm{Sr} / \mathrm{Ca}$ ratios and interstitial dissolved Sr data. J. Sediment. Petrol., 52:71-82.

Burton, E. A., and Walter, L. M., 1987. Experimental evaluation of chemical controls on marine carbonate mineralogy: implications for paleo-ocean modeling [paper presented at AAPG Research Confer- ence on Chemostratigraphy and the Evolution of the Ocean-Atmosphere System, Fort Burgwin, New Mexico.

Clauser, S., 1987. Evolution de la composition isotopique de l'oxygène des carbonates durant le Campanien et le Maastrichtien. Données préliminaires issues de la série de Bidart (Pyr. Atlantiques). $C$. $R$. Acad. Sci. Ser. 2, 11:579-594.

Edmond, J. M., Measures, C., McDuff, R. E., Chan, L. M., Collier, R., Grant, B., Gordon, L. I., and Corliss, J., 1979. Ridge crest hydrothermal activity and the balance of the major and minor elements in the ocean: the Galapagos data. Earth Planet. Sci. Lett., 46: $1-18$.

Holland, H. D., Borcsik, M., Munoz, J., and Oxburgh, U. M., 1963. The coprecipitation of $\mathrm{Sr}$ with aragonite and of $\mathrm{Ca}$ with strontianite between $90^{\circ}$ and $100^{\circ} \mathrm{C}$. Geochem. Cosmochim. Acta, 27:957-978.

Kazmierczak, J., Ittekkot, V., and Degens, E. T., 1985. Biocalcification through time: environmental challenge and cellular response. $\mathrm{Pa}$ läontol. Zeit., 59:15-33.

Kelts, K., and McKenzie, J. A., 1982. Diagenetic dolomite formation in Quaternary anoxic diatomaceous mud of DSDP Leg 64, Gulf of California. In Curray, J. R., Moore, D. G., et al., Init. Repts. DSDP, 64: Washington (U.S. Govt. Printing Office), 553-569.

Land, L. S., 1980. The isotopic and trace element geochemistry of dolomite: the state of the art. In Zenger, D. H., Dunham, J. B., Ethington, R. L. (Eds.), Concepts and Models of Dolomitization: Spec. Publ. Soc. Econ. Paleontol. Mineral., 28:87-110. 
Letolle, R., and Renard, M., 1980. Evolution des teneurs en ${ }^{13} \mathrm{C}$ des carbonates pélagiques aux limites Crétacé-Tertiaire et PaléocèneEocéne. C. R. Acad. Sci. Ser. 2, 290:827-830.

Letolle, R., Renard, M., Bourbon, M., and Filly, A., 1978. Oxygen 18 and carbon 13 isotopes in Leg 44 carbonates: a comparison with the alpine series. In Benson, W. E., Sheridan, R. E., et al., Init. Repts. DSDP, 44: Washington (U.S. Govt. Printing Office), 567-574.

MacKenzie, F. T., and Pigott, J. D., 1981. Tectonic controls of Phanerozoic sedimentary rock cycling. J. Geol. Soc. London, 138:183-196.

Milliman, J. D., 1984. Marine Carbonates: Berlin (Springer-Verlag).

Odin, G. S., 1982. Numerical Dating in Stratigraphy (Vol. 1): Chichester (Wiley).

Renard, M., 1979. Aspect géochimique de la diagenèse des carbonates. Teneurs en $\mathrm{Sr}$ et $\mathrm{Mg}$ des carbonates: essai d'interprétation de l'inversion de corrélation $\mathrm{Sr} / \mathrm{Mg}$ observée dans les carbonates du domaine pélagique par rapport à ceux du domaine néritique. Bull. Bur. Rech. Geol. Min. (Sect. 4) (Fr.), 2:133-152.

1985. Géochimie des carbonates pélagiques: mises en évidence des fluctuations de la composition des eaux océaniques depuis 140 ma. Essai de chimiostratigraphie. Doc. B.R.G.M., 85 .

,1986a. Chimisme de l'océan phénomènes géodynamiques internes \& evolution de la biosphére. Application à la crise barrémienne: la naissance de l'océan moderne. Bull. Cent. Rech. Explor. Prod. Elf Aquitaine, 10:593-606.

1986b. Pelagic carbonate chemostratigraphy $\left(\mathrm{Sr}, \mathrm{Mg} .{ }^{18} \mathrm{O}\right.$, ${ }^{13}$ C). Mar. Micropaleontol., 10:117-164.

Renard, M., Letolle, R., Bourbon, M., and Richebois, G., 1978. Some trace elements in the carbonates samples recovered from Holes 390 , $390 \mathrm{~A}, 391 \mathrm{C}$ and 392 of DSDP Leg 44. In Benson, W. E., Sheridan, R. E., et al., Init. Repts. DSDP, 44: Washington (U.S. Govt. Printing Office), 557-566.

Renard, M., Letolle, R., and Richebois, R., 1979a. Strontium, manganese, iron contents and oxygen isotopes in the carbonate samples recovered from Site 398D of Leg 47B: preliminary data. In Sibuet, J.-C., Ryan, W.B.F., et al., Init. Repts. DSDP, 47, Pt. 2: Washington (U.S. Govt. Printing Office), 497-501. $1979 \mathrm{~b}$. Some trace elements, oxygen and carbon isotopes in the carbonate samples recovered from Site $400 \mathrm{~A}$ of Leg 48 . In Montadert, L., Roberts, D. B., et al., Init. Repts. DSDP, 48: Washington (U.S. Govt. Printing Office), 727-747.

Sandberg, P. A., 1975. New interpretation of Great Salt Lake ooids and the ancient nonskeletal carbonate mineralogy. Sedimentology, 22: 497-537.
Scholle, P. A., and Arthur, M. A., 1980. Carbon isotope fluctuations in the Cretaceous pelagic limestones: potential stratigraphic and petroleum exploration tool. AAPG Bull., 64:67-87.

Schuber, N., 1984. Géochimie des carbonates, aux environs de la limite Jurassique/Crétacé, sur une transversale des zones externes des cordillères bétiques et dans le site 391C de l'Atlantique Central. Sci. Terre. Mem., 84-57.

Shackleton, N. J., 1986. Paleogene stable isotope events. Palaeogeogr., Paleoclimatol., Paleoecol., 57:91-102.

Shackleton, N. J., and Hall, M. A., 1984. Carbon isotope data from Leg 74 sediments. In Moore, T. C., Jr., Rabinowitz, P. D., et al., Init. Repts. DSDP, 74: Washington (U.S. Govt. Printing Office), 613-620.

Shipboard Scientific Party, 1987a. Site 638. In Boillot, G., Winterer, E. L., et al., Proc. ODP, Init. Repts., 103: College Station, TX (Ocean Drilling Program, 221-407.

1987b. Site 641. In Boillot, G., Winterer, E. L., et al., Proc. $O D P$, Init. Repts., 103: College Station, TX (Ocean Drilling Program, 571-649.

Sliter, W. V., and Premoli Silva, I., 1985. The Cretaceous as the time of the initiation of the modern ocean. Terra Cogn., 5:112.

Veizer, J., 1977. Diagenesis of pre-Quaternary carbonates as indicated by tracer studies. J. Sediment. Petrol., 47:565-581.

1983. Chemical diagenesis of carbonates: theory and application of trace element technique. SEPM Short Course, 10:3.13.100 .

Weissert, H., McKenzie, J., and Hochuli, P., 1979. Cyclic anoxic events in the Early Cretaceous Tethys Ocean. Geology, 7:147-151.

Weissert, H., McKenzie, J., and Channel, J.E.T., 1985. Natural variation in the carbon cycle during the Early Cretaceous. In Sundquist, E. T., and Broecker, W. S. (Eds.), The Carbon Cycle and Atmospheric $\mathrm{CO}_{2}:$ Natural Variations Archean to Present: Geophys. Monogr. Am. Geophys. Union, 32:531-544.

Wilkinson, B. H., and Given, R. K., 1986. Secular variation in abiotic marine carbonates: constraints on Phanerozoic atmospheric carbon dioxide contents and oceanic $\mathrm{Mg} / \mathrm{Ca}$ ratios. J. Geol., 94:321-333.

Date of initial receipt: 25 March 1987

Date of acceptance: 15 February 2988

Ms 103B-124 
Geochemical events
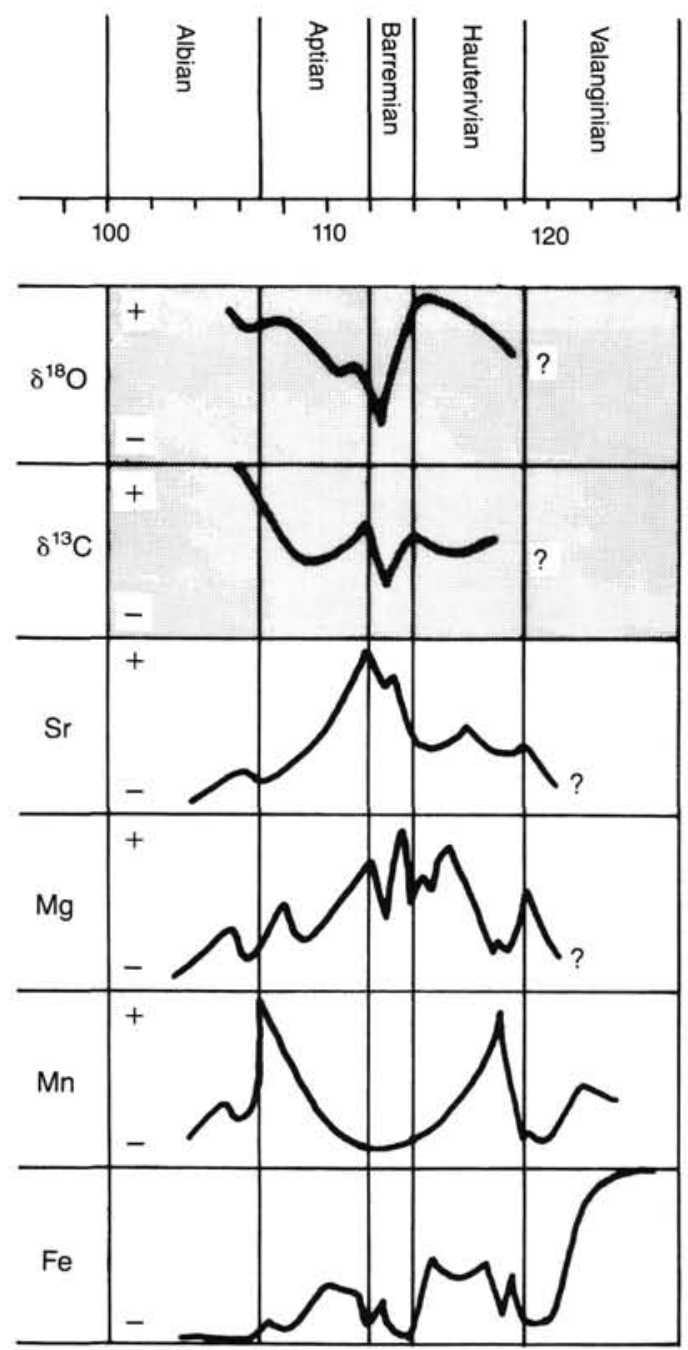

Paleoenvironmental events
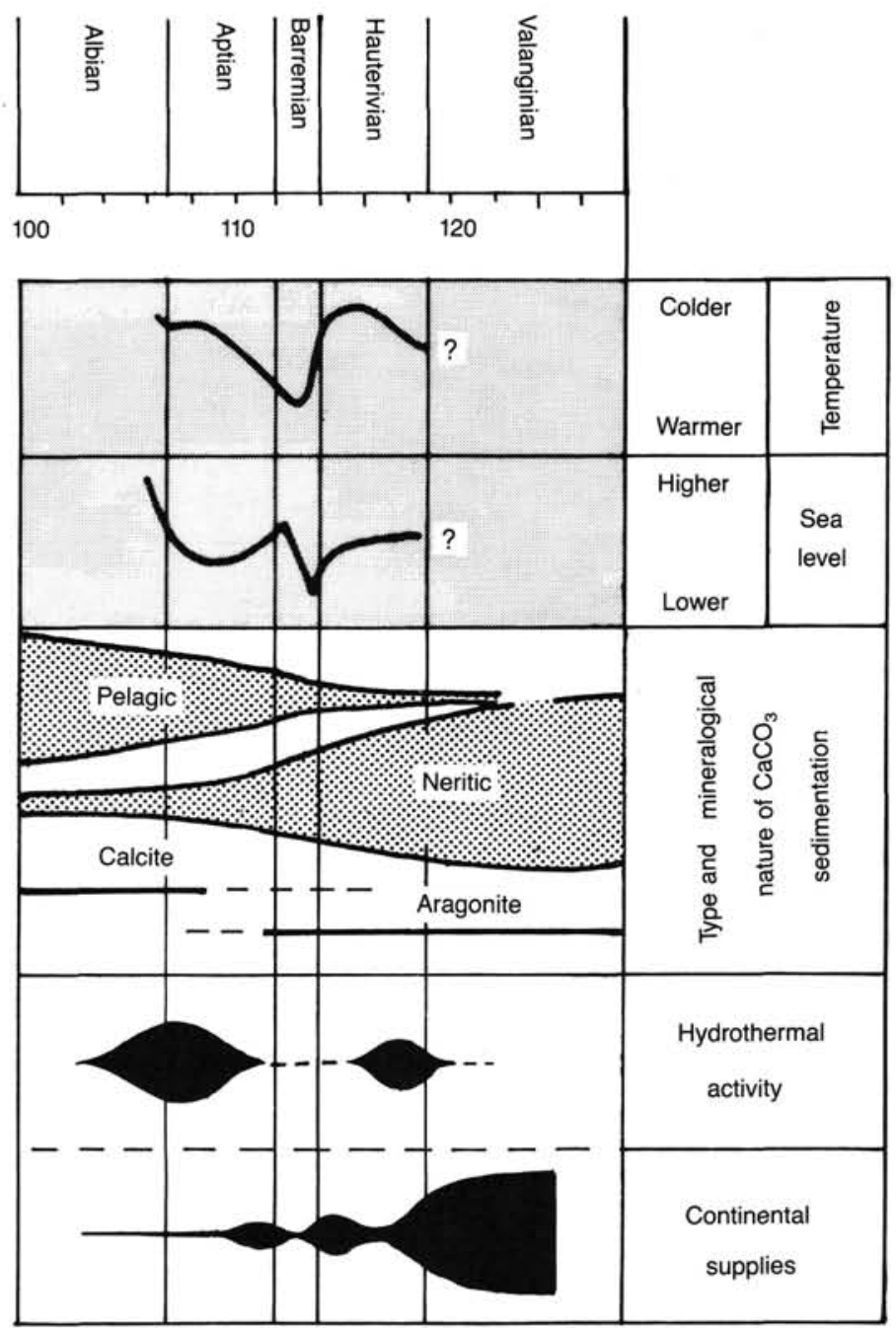

Figure 12. Schematic evolution of geochemical events recorded by carbonates from Holes 638B and 641C and hypothetical paleoenvironmental events deduced from them. 